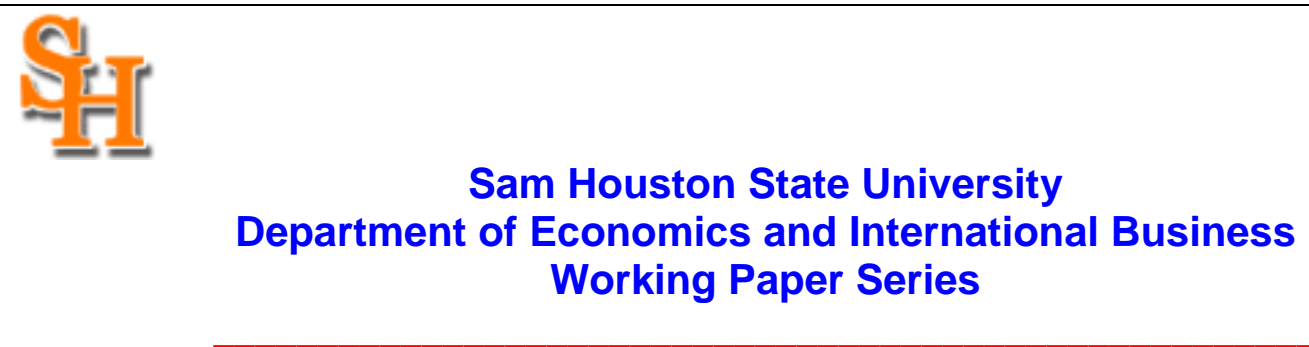

\title{
Monetary policy and the U.S. housing market: A VAR analysis imposing sign restrictions
}

\author{
Carlos Vargas-Silva \\ SHSU Economics \& Intl. Business Working Paper No. SHSU_ECO_WP07-05 \\ September 2007
}

\begin{abstract}
:
This article examines the impact of monetary policy shocks on the U.S. housing market using an identification procedure similar to the one suggested by Uhlig (Journal of Monetary Economics, 2005). The identification procedure imposes sign restrictions on the response of some variables for a certain period. No restrictions are placed on the response of the housing variable. Overall, the results indicate that housing starts and residential investment respond negatively to contractionary monetary policy shocks. However, the magnitude of the impact is sensitive to the selection of the horizon for which the restrictions hold. Moreover, a comparison of the results with those obtained from a conventional Choleski decomposition, suggests that the impact of monetary policy on the housing market is much less certain under the sign restrictions approach.
\end{abstract}

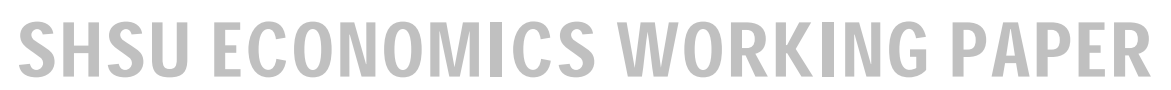




\title{
Monetary policy and the U.S. housing market: A VAR analysis imposing sign restrictions
}

\begin{abstract}
This article examines the impact of monetary policy shocks on the U.S. housing market using an identification procedure similar to the one suggested by Uhlig (Journal of Monetary Economics, 2005). The identification procedure imposes sign restrictions on the response of some variables for a certain period. No restrictions are placed on the response of the housing variable. Overall, the results indicate that housing starts and residential investment respond negatively to contractionary monetary policy shocks. However, the magnitude of the impact is sensitive to the selection of the horizon for which the restrictions hold. Moreover, a comparison of the results with those obtained from a conventional Choleski decomposition, suggests that the impact of monetary policy on the housing market is much less certain under the sign restrictions approach.
\end{abstract}

JEL classification: E52, R2, C32

Keywords: Monetary policy; Housing; VAR 


\section{Introduction}

There is plenty of evidence in the literature suggesting that the housing market is linked to aggregate economic activity in the U.S. (e.g. Iacoviello, 2005). Housing investment is an important indicator of household wealth (Case et al., 2005), and at the same time is one of the most volatile sectors of the U.S. economy (Bernanke and Gertler, 1995). The importance of the housing market is clearly visible in Figure 1, which plots the number of new privately owned housing units starts each year (solid line), and recessions as determined by the National Bureau of Economic Research (shaded areas). It is common for a large drop in housing starts to precede a recession. ${ }^{1}$

$<<$ Figure $1>>$

This article examines the impact of monetary policy innovations on the U.S. housing market. In a recent testimony before the U.S. Congress, the Chairman of the Federal Reserve Ben S. Bernanke argued that "given the substantial gains in house prices and the high levels of home construction activity over the past several years, prices and construction could decelerate more rapidly than currently seems likely. Slower growth in home equity, in turn, might lead households to boost their saving and trim their spending relative to current income by more than is now anticipated,” Federal Reserve Board (2006). The events in the housing market have a significant effect on household wealth, and thus have a big influence over household behavior. ${ }^{2}$ Therefore, a comprehensive

\footnotetext{
${ }^{1}$ The housing market is perceived as having predictive power over the future course of the economy. For instance, the Conference Board includes housing starts as an element of its Index of Leading Economic Indicators (Fratantoni and Schuh, 2003). Moreover, Green (1997) shows that there is Granger causality from housing investment to GDP, while there is no Granger causality from nonresidential investment to GDP.

${ }^{2}$ A similar view about the importance of the housing market for analyzing household behavior is shared by the former Chairman of the Federal Reserve Alan Greenspan. In a testimony before the U.S. Congress, Greenspan stated that "among the factors contributing to the strength of spending and the decline in saving
} 
analysis of the impact of monetary policy on the housing market is necessary in order to understand the impact of monetary policy on the whole economy.

There is an extensive literature on the impact of monetary policy on different sectors of the U.S. economy (for some examples in the housing sector, see Ahearne et al., 2005 and Falk, 1986). Vector autoregressive (VAR) models are commonly used to measure the impact of monetary policy innovations. VARs provide a plausible assessment of the response of macroeconomic variables to monetary policy shocks without requiring a complete structural model of the economy. However, in order to use VARs the researcher must identify the monetary policy shock.

The use of different identification schemes can alter the results significantly. For instance, McMillin (2001) shows that the choice between contemporaneous restrictions (as in Bernanke and Blinder (1992), Bernanke and Mihov (1998a), Christiano et al. (1998) and Strongin (1995)) and long-run restrictions (as in Fackler and McMillin (1998)) can deliver important differences in the magnitude and timing of the response of macroeconomic variables to monetary policy shocks.

We follow Uhlig (2005) in applying what he calls an "agnostic" identification procedure. The identification scheme imposes sign restrictions on the response of some of the variables for a certain period, while leaving the response of the main variable of interest open. We assume that a contractionary monetary policy shock does not lead to an increase in prices, non-borrowed reserves and real GDP, or decreases in the federal funds rate for a number of periods after the shock. We impose no restrictions on the response of and allowed greater access to that wealth,” Federal Reserve Board (2005). 
the measure of housing activity. Hence, the response of this variable is left "agnostically" open by the identification procedure.

The methodology proposed by Uhlig (2005) is a way to impose explicit theoretical restrictions in the estimation and, at the same time, to leave the main question of interest open. This contrasts with other identification methods used in the literature that impose informal restrictions in order to get "reasonable results." For example, if using certain specification, the results show that prices increase after a contractionary monetary policy shock, then the model is re-specified to get a more "reasonable result." These results are therefore influenced by a priori theorizing of what is a "reasonable result.” Moreover, if the results are not consistent with economic theory it is common to call the result a puzzle, as in Sims (1992). In our approach we want to be explicit about the restrictions that we are imposing and not depend on informal restrictions (see Canova and de Nicoló (2002) and Faust (1998) for more on this topic).

Several authors have previously used other identification schemes to study the impact of monetary policy shocks and money supply shocks on the housing market using VARs. Lastrapes (2002) studied the effect of money supply shocks on the housing market using two identification procedures. First, he assumed that money supply shocks were neutral in the long-run (long run restrictions as in Blanchard and Quah, 1989). Second, he assumed a block-recursive structure in which housing variables do not affect monetary policy contemporaneously. The results suggest that money supply shocks have a positive impact on different measures of house sales. The results are robust to the use of different identification schemes (see Lastrapes and Potts (2006) for more on the impact of money supply shocks in the housing market). Wheeler and Chowdhury (1993) and Hasan and 
Taghavi (2002) used a recursive structure with the monetary policy variable before residential investment in the ordering to study the impact of macroeconomic variables in the housing market. Results based on variance decompositions and historical decompositions suggest that monetary policy has important effects on residential investment.

Although these studies have provided valuable insights about the impact of monetary policy shocks and money supply shocks on the housing market, these studies imposed restrictions on the response of the housing variable to monetary policy shocks. We impose explicit restrictions on other variables, but not on the response of the housing variable. For comparison purposes we also present the results when the conventional Choleski decomposition is used to identify the monetary policy shock.

The remainder of the article is organized as follows. Section 2 discusses the data and the identification procedure. Section 3 presents the impulse response functions when sign restrictions are imposed, while Section 4 reports the impulse response functions when the Choleski decomposition is used to identify the monetary policy shock. Section 5 concludes.

\section{Identification procedure and data description}

In the estimation we focus on identifying only the monetary policy shock. We do not aim to identify all structural shocks. That is, we want to identify one impulse vector. The identification is achieved imposing sign restrictions. We assume that following a contractionary monetary policy shock, the responses of prices, non-borrowed reserves and real GDP are non-positive, while the response of the federal funds rate is nonnegative for a certain period. No restrictions are placed on the response of the housing 
activity variable. Please refer to the Appendix for more details about the estimation and to Uhlig (2005) for a complete discussion

A critical choice in the estimation is for how long the restrictions should hold after the shock. There is no simple way of choosing one horizon over another. Therefore, we compare the results using different horizons. We present the results for horizons of 3 , 6, 9, 12 and 24 periods. $^{3}$

Two alternative measures of housing market activity are used. The first measure is the number of new privately owned housing units starts (housing starts). The data used by the U.S. Census Bureau to construct this variable is obtained form the Survey of Construction (SOC). The SOC reports monthly estimates of housing starts. According to the U.S. Census Bureau in order to collect the data “Census Bureau 'field representatives' sample individual permits within a sample of permit offices. Then the builders or owners who took out the sampled permits are interviewed to obtain start and completion dates along with sale dates and characteristics such as size and number of bedrooms. In addition, within a sample of land areas where building permits are not required, field representatives drive all roads looking for new residential construction activity,” U.S. Census Bureau (2006). ${ }^{4}$

The second measure of housing market activity is the real private residential fixed investment (residential investment). According to the U.S. Bureau of Economic Analysis, residential fixed investment "consists of all private residential structures and of residential equipment that is owned by landlords and rented to tenants. Residential

\footnotetext{
${ }^{3}$ Faust (1998) also imposes sign restrictions on monetary policy shocks. Different from Uhlig (2005) the restrictions in Faust (1998) do not extend to various periods after the shock.

${ }^{4}$ As an alternative to housing starts, all the estimations were replicated using building permits. Results are consistent for both variables.
} 
structures consists of new construction of permanent-site single family and multifamily units, improvements (additions, alterations, and major structural replacements) to housing units, expenditures on manufactured homes, brokers' commissions on the sale of residential property, and net purchases of used structures from government agencies,” U.S. Bureau of Economic Analysis (2006).

Table 1 reports some descriptive statistics of these two measures of housing market activity. The first five rows in Table 1 report correlation coefficients between the growth rates of the two variables (including leads and lags of residential investment). The correlation between the measures of housing activity is about 24 percent, but decreases with lags of residential investment.

$<<$ Table $1>>$

As an alternative to the national level measures of housing activity we include a series of regional housing variables. The regional housing variables are housing starts in the Northeast, Midwest, South and West. Figure 2 plots housing starts divided by U.S. regions. The South is consistently the region with a larger number of housing starts. Since the beginning of the 1990s, housing starts in the other regions have remained at approximately the same level each year, while the South continues to grow. Notice also that for all regions there is a decrease in the volatility of housing starts since the 1980s. This decrease in volatility may be the result of the financial deregulation process of the U.S. Since the 1980 s the housing finance system has gone from being a heavily regulated system to be a relatively unregulated system (McCarthy and Peach, 2002). ${ }^{5}$

$<<$ Figure 2>>

\footnotetext{
${ }^{5}$ It is also possible to argue that the impact of monetary policy shocks on the housing market has changed because of the financial deregulation process. See Hasan and Taghavi (2002), McCarthy and Peach (2002) and Wheeler and Chowdhury (1993) for more on that topic.
} 
Each VAR includes one of the housing variables (housing starts or residential investment). ${ }^{6}$ In addition, all VARs include the following variables: real GDP, house prices (price index of new one-family houses sold), the GDP price deflator, a commodity price index (Dow-Jones index of spot commodity prices), total reserves, non-borrowed reserves and the federal funds rate. These variables, with the exception of the commodity price index and house prices, are obtained from the database of the Federal Reserve Bank of St. Louis. The commodity price index is obtained from Global Financial Data, Inc., while the house prices are obtained from the U.S. Census Bureau. The VAR is estimated in levels, which means that restrictions are imposed on the impulse response and not in the cumulative responses. The VAR includes 12 lags, the equivalent of a year.

All variables are in monthly frequency for the period 1965:1 to 2005:12. Monthly observations for real GDP, the GDP deflator and residential investment are obtained by interpolation. The real GDP series is obtained by interpolation using industrial production. Monthly observations for the GDP deflator are obtained by interpolation using the consumer price index and the producer price index. Finally, monthly observations for real private residential fixed investment are obtained by interpolation using the number of new one-family houses sold. The interpolation process follows Bernanke et al. (1997). The selection of the variables (with the exception of the housing variables) follows Bernanke and Mihov (1998a) and Uhlig (2005). All variables, with the exception of the federal funds rate, are used in logarithms.

\footnotetext{
${ }^{6}$ We could also include both variables in the same estimation. However, this approach has two limitations. First, there is the problem of degrees of freedom given that our system has already eight variables. Second and more important, we have the issue of which of these variables we choose to impose sign restrictions and what is the possible impact on the other variable.
} 


\section{Results using the sign restrictions}

This article uses impulse response functions derived from a VAR to study the impact of monetary policy on the U.S. housing market. The identification procedure imposes restrictions on the response of the GDP deflator, house prices, a commodity price index, non-borrowed reserves, real GDP and the federal funds rate for a number of periods after a monetary policy shock. No restrictions are placed on the response of the measure of housing market activity (housing starts or residential investment).

Figure 3 shows the response of the variables to a monetary policy shock when the housing market activity level is represented by housing starts. In Figure 3 and in the figures that follow, the upper and lower bounds represent a two-standard deviation band. Following Uhlig (2005), in the baseline model (Figure 3) the restrictions are imposed for six periods. The first period corresponds to the period of the shock. Hence, the restrictions are in place for five months after the initial shock.

Before examining how monetary policy impacts housing starts, we first review the impact of monetary policy on the other variables. Keep in mind that sign restrictions are used in the estimation. First, notice that within a year the federal funds rate raises by more than 30 basis points. The impact remains significant for about 8 months after the shock. This response of the federal funds rate is smaller than the estimated response in other studies related to the housing market. For instance, using a Choleski decomposition (with the federal funds rate as the monetary policy variable), Erceg and Levin (2006) estimated the initial response of the federal funds rate to be above 50 basis points. From Figure 3, we also see that the initial drop in non-borrowed reserves exceeds $1 \%$. The 
impact is significant for over 10 months. The initial impact on total reserves is negative and the initial drop in total reserves is less than $1 \%$.

Now consider the impact on prices. The price deflator drops less than $.10 \%$ after 10 months and about .36\% within 40 months. The drop in commodity prices is close to $1 \%$ after 10 months and is significant for more than 30 months. House prices drop about $.25 \%$ within 10 months and about $.60 \%$ within 40 months. This contrasts with the initial positive response of house prices after a contractionary monetary policy shock obtained by McCarthy and Peach (2002). They referred to this result as a "home price puzzle."7 In our estimation the "home price puzzle" is avoided by construction.

None of these results seems to be particularly striking. This is, mainly, because we are imposing sign restrictions in the estimation. Our main interest, however, is with respect to the housing market activity variable. From Figure 3, we see that housing starts decrease after a contractionary monetary policy shock, but the response is only significant in one period and the initial drop is less than $1 \%$. Thus, even with a decrease in house prices that lasts more than 40 months, the response of housing starts is shortlived.

$<<$ Figure 3 $>>$

In Figure 4, we substitute housing starts with residential investment. We want to check if the results for the housing activity variable are particular to housing starts or also hold for other measures of housing market activity. In general, the results in Figure 4 are similar to those in Figure 3, but there is an important difference. In contrast to the findings presented in Figure 3 (in which we included housings starts), residential investment is not responding significantly to the contractionary monetary policy shock.

\footnotetext{
${ }^{7}$ The discussion on McCarthy and Peach (2002) is based on their post-1986 estimation.
} 
$<<$ Figure $4>>$

There are two important issues related with the previous estimations. First, we are using national level variables to measure housing activity. As we showed in Figure 2, there are important regional differences in the U.S. housing market. Second, the horizon for which the restrictions hold is selected ad-hoc. A different horizon for the restrictions may yield a different result. Next, we explore these two issues.

\subsection{Regional models}

Carlino and DeFina (1998, 1999), among others, have suggested that the impact of monetary policy on the U.S. economy can differ across regions. Economic conditions prevailing at the time of the monetary policy shock may not be the same across regions. Moreover, the sensitivity of the regions to monetary policy shocks may be different. In Figure 5, we plot the response of housing starts by region, to a monetary policy shock. The horizon for the restrictions remains as six periods.

In all regions, the initial response of housing starts to a contractionary monetary policy shock is negative. However, only in the Northeast and the Midwest is the response significant for more than one period. As we mentioned above, most of the housing activity in the U.S. is taking place in the South. This fact, combined with the similarity of the response of housing starts in the South, to the response of housing starts at the national level (see Figure 3) suggests that the dynamics of the U.S. housing market are largely driven by the South. The response of all other variables to the monetary policy shock is, in all cases, similar to the response reported in Figure $2 .^{8}$

$<<$ Figure 5 $>>$

\footnotetext{
${ }^{8}$ See Fratantoni and Schuh (2003) for more on the regional impact of monetary policy on the housing market.
} 


\subsection{Different horizons}

In the estimation the selection of the horizon for which the restrictions hold is adhoc. Other authors using the same identification procedure have selected different horizons for the sign restrictions. For instance, Scholl and Uhlig (2006) used a 12 month horizon to study the impact of monetary policy on exchange rates, while Uhlig (2005) used horizons of 3, 6, 12 and 24 months to study the impact of monetary policy on output. For completeness, we must check the results using different horizons. Figure 6 plots the response of housing starts (top) and residential investment (bottom), when the restrictions are imposed for 3, 9, 12 and 24 periods. Figure 6 indicates that as we expand the horizon under which the restrictions hold (i.e. longer horizon), the response of the housing market activity variable to a contractionary monetary policy shock lasts for a longer period. This is especially the case for residential investment. For instance, when the horizon is 3 periods the response of residential investment is not significant, while when the horizon is 9 periods the response is significant. In this case (horizon $=9$ ), the initial drop in housing starts is close to $1 \%$, while residential investment drops by about $.5 \%$. Moreover, when the horizon is 24 periods housing starts also drop by about $1 \%$, while the drop in residential investment exceeds $.5 \%{ }^{9}$

$<<$ Figure $6>>$

Several studies have previously reported a negative response of residential investment to monetary policy shocks. For instance, Erceg and Levin (2006) showed that the initial response to a contractionary monetary policy shock of an index of consumer durables and residential investment is negative (they estimated the drop to be close to .7

\footnotetext{
${ }^{9}$ Similar results were obtained for the different regions. Results are available upon request.
} 
percent). Iacoviello and Neri (2007) using a small-scale dynamic stochastic general equilibrium model estimated a drop in residential investment in response to a monetary policy shock that exceeded 3 percent. McCarthy and Peach (2002) estimated the initial drop of residential investment after a monetary policy shock to be close to 3 percent in both the pre-deregulation and post-deregulation periods. Our results suggest that the response is smaller (about .5 percent), but this does not necessarily imply a non-relevant response of the housing market to monetary policy shocks. Residential investment accounts for about 4 to 6 percent of GDP, which implies that a reduction of $.5 \%$ in residential investment has important economic consequences.

\section{Results using the Choleski decomposition}

One of the main critiques of the Choleski decomposition is that it is not unique, which means that results for impulse response functions will depend on the ordering of the variables. A possible solution is to try different orderings and compare the impulse response functions for each ordering. But this will only be valid if it is known that the true model is recursive (rare in economics), and only the ordering is unknown (Fackler, 1990). ${ }^{10}$

In order to impose a recursive structure, we must select the ordering of the variables. Furthermore, we have to choose one variable whose innovations will be interpreted as monetary policy shocks. Following Bernanke and Blinder (1992), shocks to monetary policy are defined as a one-unit standard deviation shock to the federal funds

\footnotetext{
${ }^{10}$ An alternative is to use generalized impulse response functions as in Pesaran and Shin (1998). See Ewing and Wang (2005) for an application of this methodology to the housing market.
} 
rate. ${ }^{11}$ We use two alternative orderings in the estimation. The first ordering is: real GDP, housing variable, house prices, GDP price deflator, the commodity price index, the federal funds rate, nonborrowed reserves and total reserves. In this case, nonborrowed reserves and total reserves respond contemporaneously to monetary policy shocks, while the other variables respond to innovations in monetary policy with one lag. In the second ordering we place the measure of housing market activity (housing starts or residential investment) after the federal funds rate.

While for reasons of space we do not report the responses of all variables to a monetary policy shock under the recursive structure, a few words regarding the response of the federal funds rate are in order. The initial raise in the federal funds rate is above 60 basis points, the impact remains close to 50 basis points after one year. This response is bigger than the response obtained under the sign restrictions and it is also closer to the response obtained by Erceg and Levin (2006). ${ }^{12}$

The responses of housing starts and residential investment under the recursive structure are presented in Figure 7. In both cases, the response is negative and significant. The response is significant for almost 30 months for housing starts and for about 40 months for residential investment. In the estimations with the sign restrictions, only the response of residential investment when the restrictions horizon is 24 periods is significant for more than 30 months. In all other cases under the sign restrictions, the response lasts for a shorter period than the case with the Choleski decomposition.

\footnotetext{
11 Other papers (e.g. Christiano et al., 1996) prefer to use non-borrowed reserves as the monetary policy variable. See McMillin (2001) for a broader discussion on the selection of the monetary policy variable.

${ }^{12}$ A complete set of results using the Choleski decomposition is available from the authors upon request. The response of all the variables included in the estimation is similar across the alternative orderings.
} 
It is also important to notice the difference in the size of the impact. Using the sign restrictions the initial drop in housing starts after the contractionary monetary policy shock is about $1 \%$. The impact is much bigger in the case of the Choleski decomposition. With the Choleski, the initial impact is close to $3 \%$. The impact is also bigger for residential investment. In the estimation with sign restrictions the estimated impact on residential investment is about $.5 \%$, while with the Choleski decomposition the estimated impact is close to $2 \%$.

$<<$ Figure 7>>

There is also a difference in the fraction of the variance in housing that monetary policy shocks explain when sign restrictions and the Choleski decomposition are used. Using the Choleski decomposition, results from variance decompositions suggest that monetary policy shocks account for 11 to $14 \%$ of the variations in housing starts. On the other hand, the sign restrictions approach indicates that monetary policy shocks account for only 4 to $5 \%$ of the variations in housing, a fraction that is not significant. ${ }^{13}$

\section{Summary and conclusion}

This article has examined the relationship between monetary policy and the U.S. housing market using an identification procedure similar to the one suggested by Uhlig (2005). The identification scheme imposes sign restrictions on the response of some of the variables for a number of periods after a monetary policy shock. We assume that shocks to monetary policy do not lead to increases in the GDP deflator, house prices, a commodity price index, non-borrowed reserves and real GDP, or decreases in the federal funds rate for a certain period. No restrictions are placed on the response of the housing

${ }^{13}$ Other results from the variance decompositions suggest that monetary policy shocks explain about $10 \%$ of the variation in housing prices after 24 periods. Results from variance decompositions are not shown but are available from the authors upon request. 
market activity variable (housing starts or residential investment). The response of the housing variable is left "agnostically” open by the identification procedure.

Overall, the results suggest that contractionary monetary policy shocks have a negative impact on housing starts and residential investment. The response is, in general, similar across U.S. regions. However, the impact of monetary policy on housing seems to be stronger in the Midwest. When the horizon for which the restrictions are imposed is expanded (to 9, 12 or 24 periods), the impact of a monetary policy shock lasts for a longer period (especially for residential investment).

A comparison with the results obtained using the conventional Choleski decomposition reveals important differences. In the estimation with sign restrictions the response of the housing activity variable to a monetary policy shock is smaller and lasts for a shorter period than in the case with the Choleski decomposition. Moreover, there are cases under the sign restrictions for which we fail to find a significant response of the housing variable to the monetary policy shock. Once we become "agnostics" about the impact of monetary policy on the housing market, the results suggest that the impact is much less certain. 


\section{References}

Ahearne, A., Ammer, J., Doyle, B., Kole, L., Martin, R., 2005. Monetary policy and house prices: a cross-country study. Board of Governors of the Federal Reserve System (U.S.), International Finance Discussion Papers 841.

Bernanke, B.S., Blinder, A., 1992. The federal funds rate and the channels of monetary transmission. American Economic Review 82, 901-21.

Bernanke, B.S., Gertler, M., 1995. Inside the black box: the credit channel of monetary policy transmission. The Journal of Economic Perspectives 9, 27-48.

Bernanke, B.S., Gertler, M., Watson, M., 1997. Systematic monetary policy and the effects of oil price shocks. Brooking Papers on Economic Activity 1, 91-157.

Bernanke, B.S., Mihov, I., 1998a. Measuring monetary policy. Quarterly Journal of Economics 113, 869-902.

Bernanke, B.S., Mihov, I., 1998b. The liquidity effect and long-run neutrality. Carnegie Rochester Conference Series on Public Policy 49, 149-194.

Blanchard, O.J., Quah, D., 1989. The dynamic effects of aggregate demand and supply disturbances. American Economic Review 9, 655-673.

Canova, F., de Nicoló, G., 2002. Monetary disturbances matter for business fluctuations in the G-7. Journal of Monetary Economics 49, 1131-1159.

Carlino, G.A., DeFina, R.H., 1998. The differential regional effects of monetary policy. The Review of Economics and Statistics 80, 572-587.

Carlino, G.A., DeFina, R.H., 1999. Do states respond differently to changes in monetary policy? Business Review, July/August, 17-27.

Case, K., Shiller, R., Quigley, J., 2005. Comparing wealth effects: the stock market versus the housing market, Advances in Macroeconomics, 5.

Christiano, L., Eichenbaum, M., Evans, C., 1996. The effects of monetary policy shocks: evidence from the flow of funds. The Review of Economics and Statistics 78, 1634.

Christiano, L., Eichenbaum, M., Evans, C., 1998. Monetary policy shocks: what have we learned and to what end? National Bureau of Economic Research, Working Paper 6400.

Erceg, C., Levin, T., 2006. Optimal monetary policy with durable consumption goods. Journal of Monetary Economics 53, 1341 - 1359.

Ewing, B.T., Wang, Y., 2005. Single housing starts and macroeconomic activity: an application of generalized impulse response analysis. Applied Economic Letters $12,187-190$.

Fackler, J.S., 1990. Federal credit, private credit, and economic activity. Journal of Money, Credit, and Banking 22, 444-464.

Fackler, J.S., McMillin, W.D., 1998. Historical decomposition of aggregate demand and supply shocks in a small macro model. Southern Economic Journal 64, 648-664.

Falk, B., 1986. Unanticipated money-supply growth and single-family housing starts in the U.S.: 1964-1983. Housing Finance Review 5, 15-23.

Faust, J., 1998. The robustness of identified VAR conclusions about money. CarnegieRochester Conference Series on Public Policy 49, 207-244.

Federal Reserve Board (2005) Testimony of Chairman Alan Greenspan, Federal Reserve Board's semiannual Monetary Policy Report to the Congress, Before the 
Committee on Banking, Housing, and Urban Affairs, U.S. Senate, February 16, 2005.

Federal Reserve Board (2006) Testimony of Chairman Ben S. Bernanke, Semiannual Monetary Policy Report to the Congress, Before the Committee on Financial Services, U.S. House of Representatives, February 15, 2006.

Fratantoni, M., Schuh, S., 2003. Monetary policy, housing, and heterogeneous regional markets. Journal of Money, Credit and Banking 35, 557-590.

Green, R., 1997. Follow the leader: How changes in residential and non-residential investment predict changes in GDP. Real Estate Economics 25, 253-270.

Hasan, M.S., Taghavi, M., 2002. Residential investment, macroeconomic activity and financial deregulation in the UK: an empirical investigation. Journal of Economics and Business 54, 447-462.

Iacoviello, M., 2005. House prices, borrowing constraints, and monetary policy in the business cycle. American Economic Review 95, 739-64.

Iacoviello, M., Neri, S. 2007. The role of housing collateral in an estimated two-sector model of the U.S. economy. Working Paper, Boston College.

Lastrapes, W., 2002. The real price of housing and money supply shocks: time series evidence and theoretical simulations. Journal of Housing Economics 11, 40-74.

Lastrapes, W., Potts, T., 2006. Durable goods and the forward-looking theory of consumption: estimates implied by the dynamic effects of money. Journal of Economic Dynamics and Control, 30, 1409-1430.

McCarthy, J., Peach, R., 2002. Monetary policy transmission to residential investment. Economic Policy Review, May, 139-158.

McMillin, W.D., 2001. The Effects of monetary policy shocks: comparing contemporaneous versus long-run identifying restrictions. Southern Economic Journal 67, 618-636.

Pesaran, H., Shin, Y., 1998. Generalized impulse response analysis in linear multivariate models. Economics Letters 58, 17-29.

Scholl, A., Uhlig, H., 2006. New evidence on the puzzles: results from agnostic identification on monetary policy and exchange rates. Working Paper, HumboldtUniversität zu Berlin.

Sims, C.A., 1992. Interpreting the macroeconomic time series facts: the effects of monetary policy. European Economic Review 36, 975-1000.

Strongin, S., 1995. The identification of monetary policy disturbances: explaining the liquidity puzzle. Journal of Monetary Economics 35, 463-497.

Uhlig, H., 1994. What macroeconomists should know about unit roots: a Bayesian perspective. Econometric Theory 10, 645-671.

Uhlig, H., 2005. What are the effects of monetary policy on output? Results from an agnostic identification procedure. Journal of Monetary Economics 52, 381-419.

U.S. Bureau of Economic Analysis (2006) A Guide to the national income and product accounts of the United States at http://www.bea.gov/bea/an/nipaguid.pdf.

U.S. Census Bureau (2006) Relationship Between Building Permits, Housing Starts, and Housing Completions at www.census.gov.

Wheeler, M., Chowdhury, A., 1993. The housing market, macroeconomic activity and financial innovation: an empirical analysis of U.S. data, Applied Economics 25, 1385- 1392. 


\section{Appendix}

What follows is a brief summary of Uhlig's (2005) pure-sign-restriction methodology. Please refer to the original source for further details. We want to define a monetary policy impulse vector as one in which the sign restrictions hold. That is, a monetary policy impulse vector is an impulse vector, so that the responses of prices, real GDP and nonborrowed reserves are non-positive and the response of the federal funds rate is non-negative at all horizons $k=0, . ., K$. Because of identification issues, Uhlig recommends that we supplement the identification assumption by imposing a prior. The prior is proportional to a Normal-Wishart (see Uhlig (1994) for details).

Empirically, the procedure is as follows:

1) Take $n_{1}$ draws from the VAR posterior and $n_{2}$ draws from an independent uniform prior (see Uhlig (2005) for details).

2) Construct the impulse vector.

3) For each draw, calculate the impulse responses at horizon $k=0, . ., K$.

4) Check if the impulse response functions satisfy the sign restrictions.

5) If all the impulse response functions satisfy the sign restrictions keep the draw. If any of the impulse response functions do not satisfy the sign restrictions discard the draw. Stop after obtaining $n_{3}$ impulse response functions with the desired sign. The error bands are calculated using the draws kept.

In the estimation we used $n_{1}=n_{2}=2,000, n_{3}=1,000$ and $K=3,6,9,12$ and 24 . 


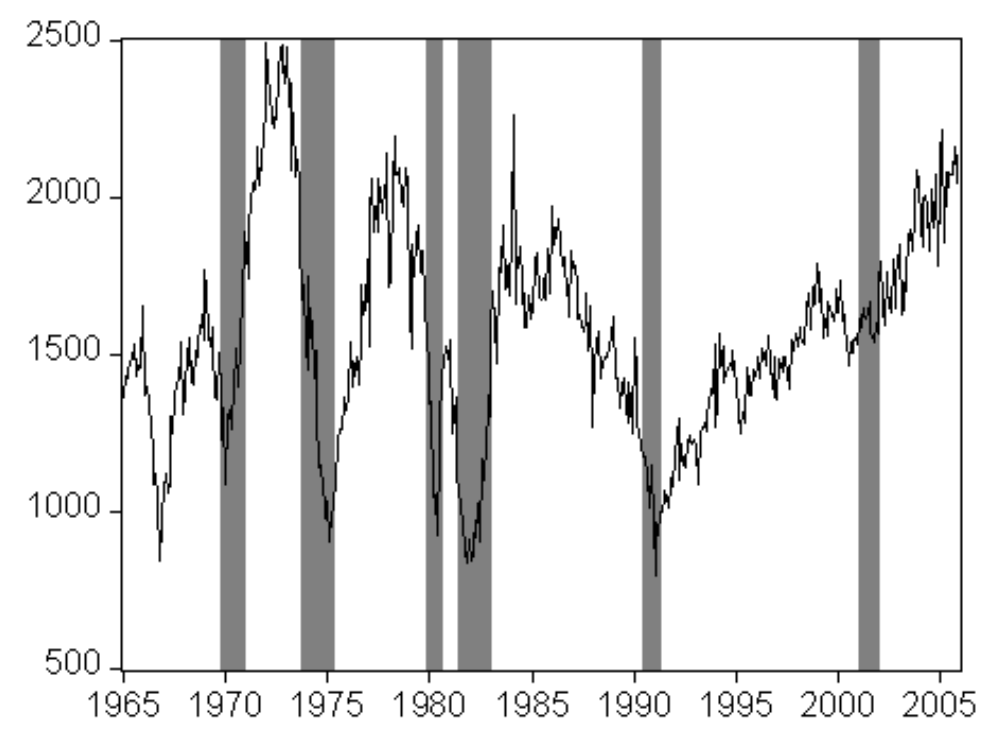

Figure 1 - Housing starts (thousand units, annualized) and recessions as determined by the NBER (shaded areas). Source: U.S. Census Bureau.

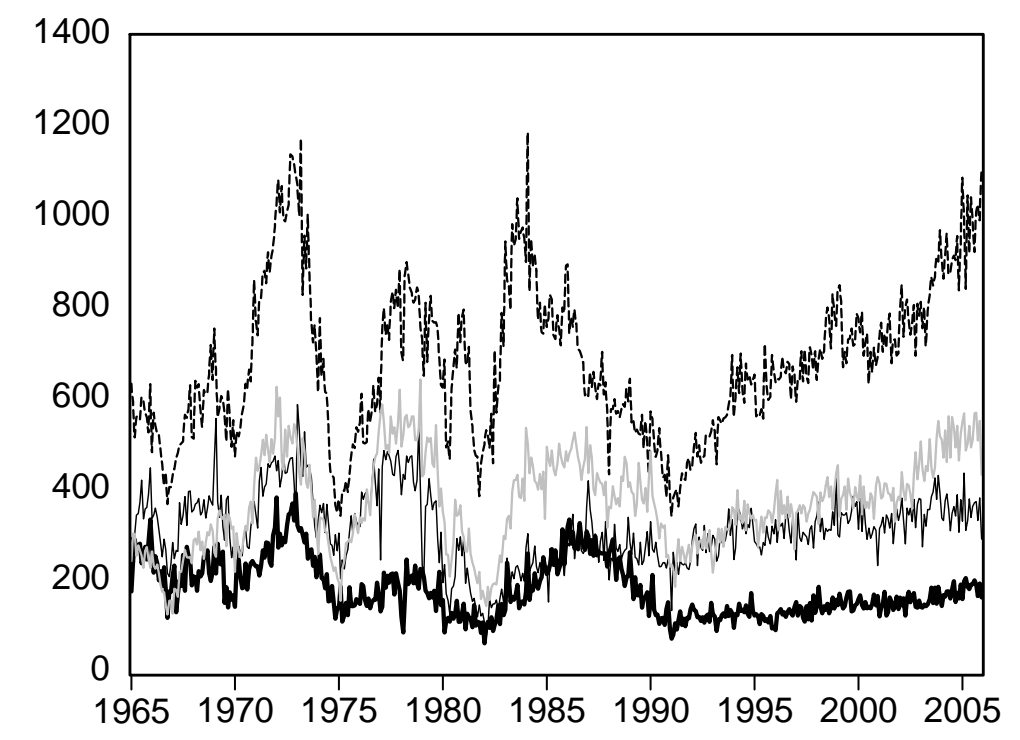

Figure 2 - Housing starts (thousand units, annualized) divided by regions. South (dashed), West (solid, light), Midwest (solid) and Northeast (solid, bold). Source: U.S. Census Bureau. 


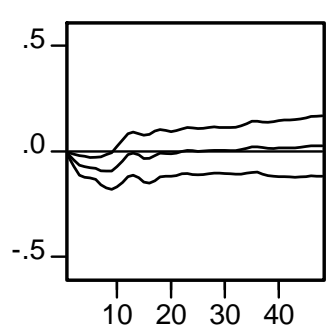

Real GDP

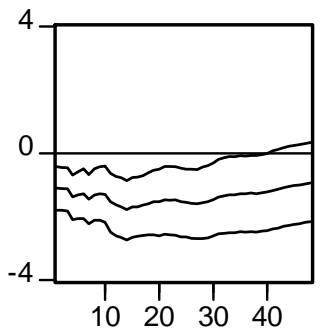

Commodity Price

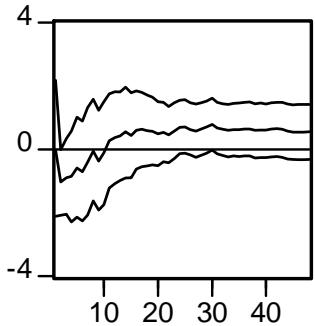

Housing Starts

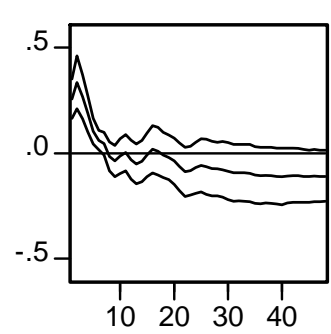

Federal Funds Rate

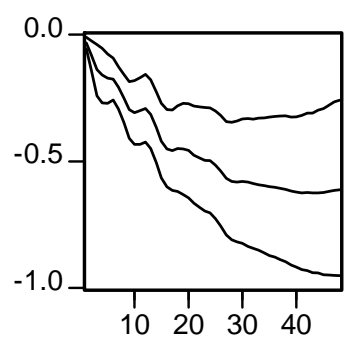

House Prices

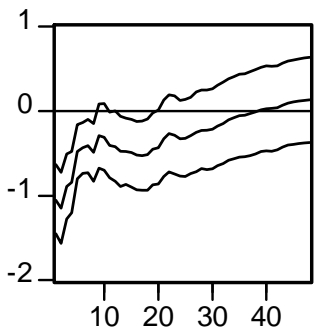

Nonborrowed Reserves

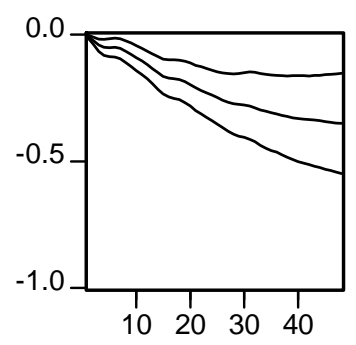

Price Deflator

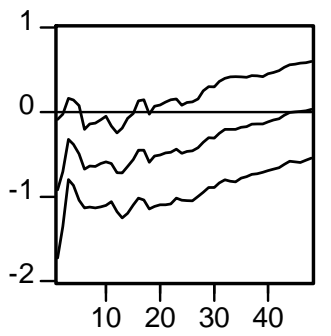

Total Reserves

Figure 3 - Response to a contractionary monetary policy shock one standard deviation in size. Restrictions are in place for 6 periods. Housing stars are included in the estimation.

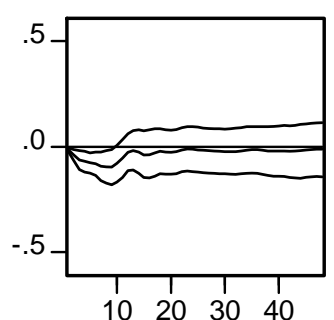

Real GDP

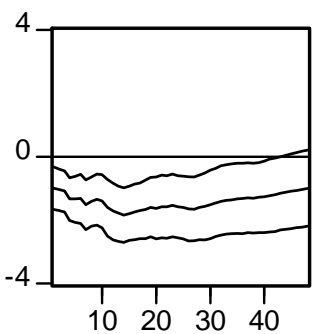

Commodity Price

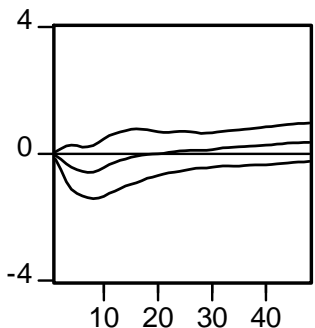

Residential Investment

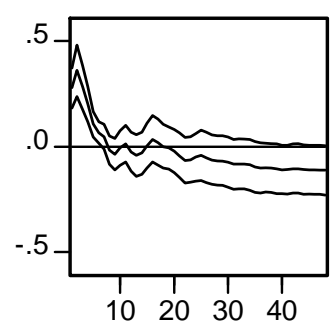

Federal Funds Rate

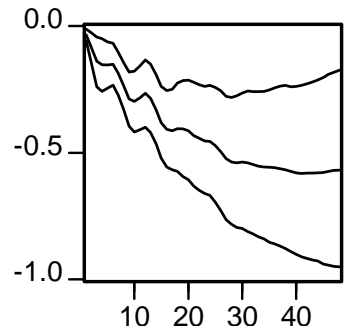

House Prices

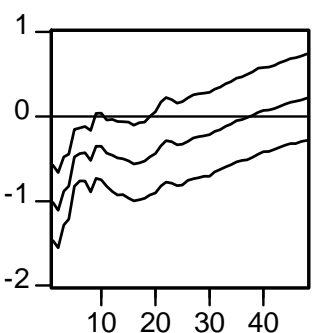

Nonborrowed Reserves

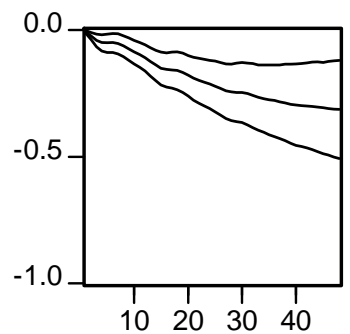

Price Deflator

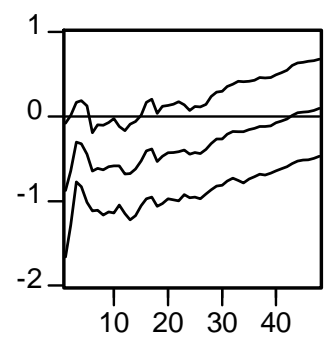

Total Reserves

Figure 4 - Response to a contractionary monetary policy shock one standard deviation in size. Restrictions are in place for 6 periods. Residential investment is included in the estimation. 

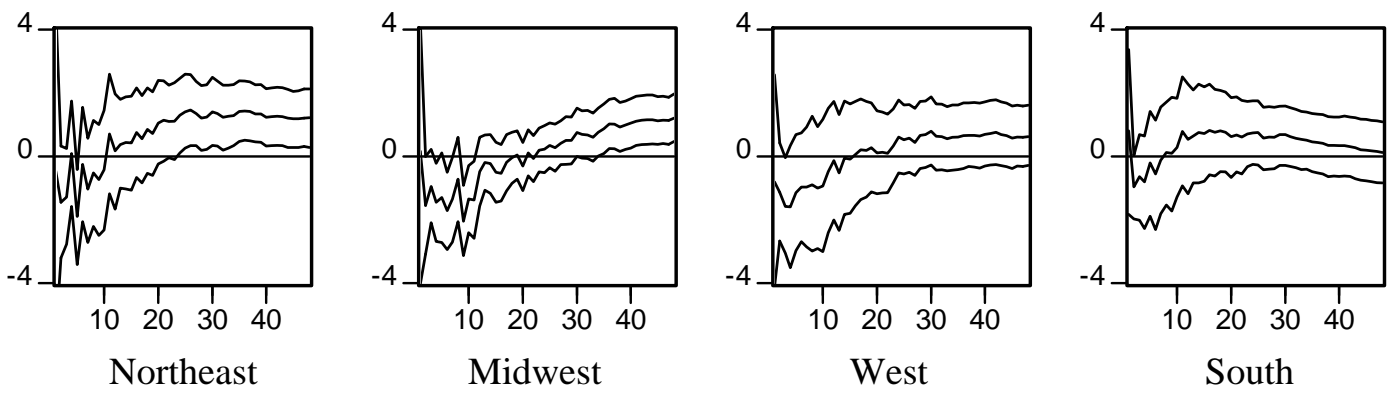

Figure 5 - Response of housing starts by U.S. region to a contractionary monetary policy shock one standard deviation in size. Restrictions are in place for 6 Periods.
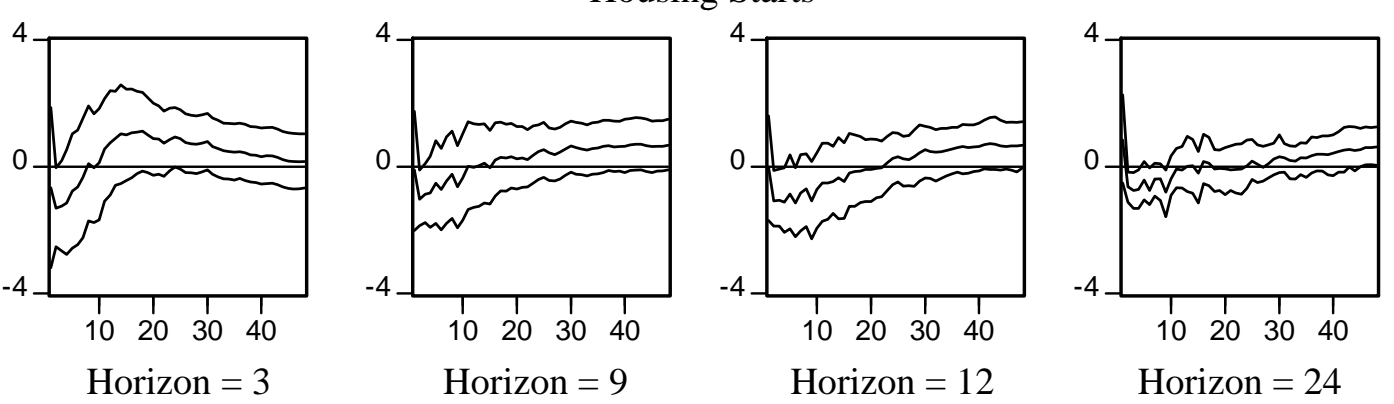

\section{Residential Investment}
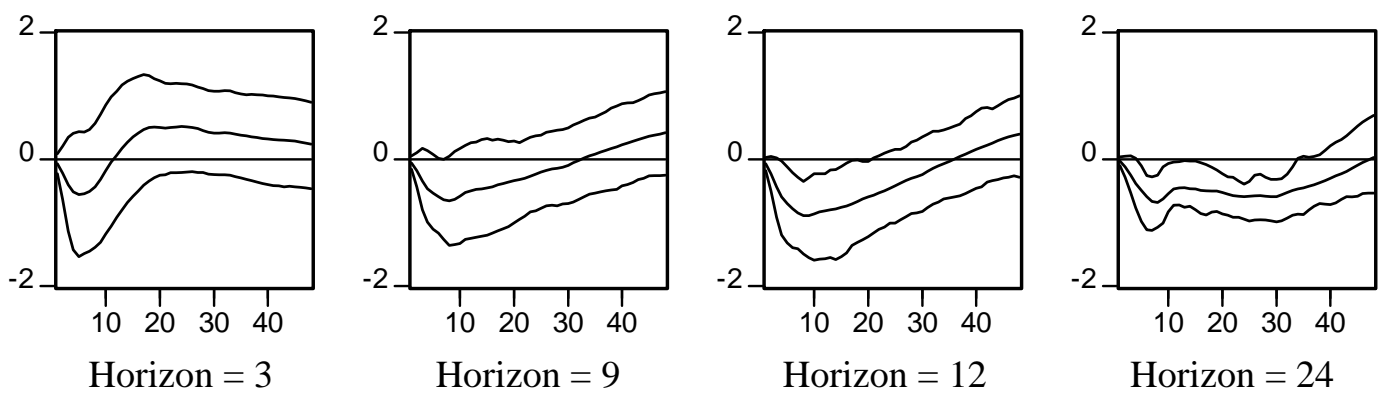

Figure 6 - Response of housing starts and residential investment to a contractionary monetary policy shock one standard deviation in size, using different horizons for the restrictions. 


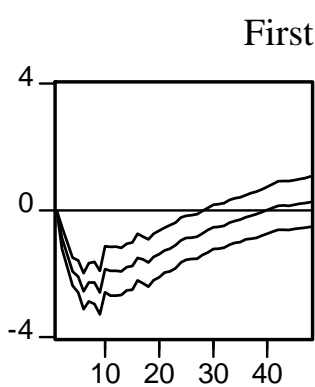

Housing Starts

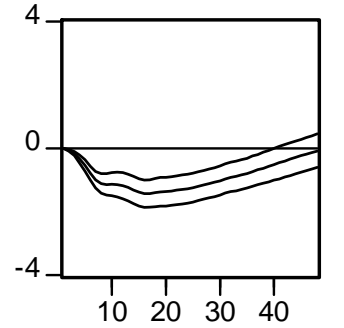

Residential Investment
Second ordering
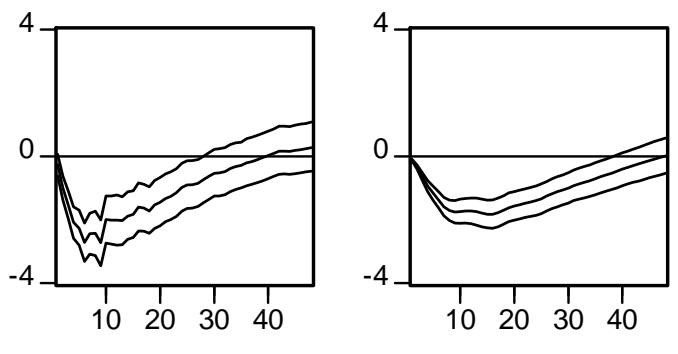

Residential Investment

Figure 7 - Response of housing starts and residential investment to a contractionary monetary policy shock using the Choleski decomposition. The monetary policy shock corresponds to one standard deviation in the federal funds rate. 


\begin{tabular}{lcc}
\hline & Housing Starts & Residential Investment \\
\hline Correlations & & \\
Residential Investment (2 Leads) & 28.7 & 58.6 \\
Residential Investment (1 Lead) & 30.1 & 86.0 \\
Residential Investment & 24.3 & 100.0 \\
Residential Investment (1 Lag) & 14.5 & 86.0 \\
Residential Investment (2 Lags) & 4.8 & 58.6 \\
Mean & 1559.9 & 316.6 \\
Standard Deviation & 337.2 & 105.6 \\
N & 492 & 492 \\
\hline
\end{tabular}

Table 1 - Descriptive statistics of housings starts (thousand units, annualized), and residential investment (billion of chained 2000 dollars). Correlations are estimated using growth rates. 